\title{
Evaluating an Integrated EFL Teaching Methodology in Saudi Universities: A Longitudinal Study
}

\author{
Mohamed Amin Mekheimer \\ English Department, College of Languages \& Translation, King Khalid University, Saudi Arabia \\ Hamad Shabieb Aldosari
English Department, College of Languages \& Translation, King Khalid University, Abha, Saudi Arabia
}

\begin{abstract}
This study aimed to investigate the effectiveness and suitability of the integrated holistic method for teaching EFL skills embedded in an Oxford ${ }^{\circledR}$ series of courses selected for study at the lower-to-upper intermediate levels of learning EFL, namely Open Forum 3, Well Read 3 - Effective Academic Writing2. Participants of the study were selected from the population of students in a Southwestern Saudi university. The sample included 52 participants in intermediate levels. Researchers employed a pre-test, posttest control group design in a quasi-experimental method to evaluate the instructional effectiveness of the integrated holistic teaching method. Findings indicate that the treatment in this study, the Integrated Skills Treatment, had a significant effect on student performance in all skills presented instructionally according to an integrated, holistic approach. Further findings showed that the experimental group participants achieved improvements in gain scores compared with their peers in the control group on the tested language skills, namely listening and speaking, reading, and writing. Qualitative data from a follow-up questionnaire study asserted the effectiveness and appropriateness of an integrative pedagogy to teaching EFL skills. The paper, in the end, provides a set of relevant implications and recommendations for further pedagogical practice and further research implications.
\end{abstract}

Index Terms —integrated language teaching, skill-based learning, holistic teaching, EFL skills, performance, longitudinal research

\section{INTRODUCTION}

Evaluation research has come to the fore positively as "a main source of organizational learning, lessons learned, collaboration and utilization" (Arkin, 2010, p. 3339) which draws a contour between the contemporary concept of evaluation and the traditional, negative perspective concept of the term recognised in the literature of language evaluation programmes (Morabito 2002; Patton 2001; Preskill 1994; Sullivan and Sullivan 1998; Torres and Preskill 2001). The import of evaluation studies has been recognised as judging the "worth, merits and shortcomings of various educational programmes" (Luo \& Dappen, 2004, p. 109). As such, it functions to improve and assure the educational quality of the English language programme in any given language and translation college. The objectives of evaluation research has been identified by Worthen et al, (1997) to include: 1) determining standards for judging quality and decide whether those standards should be relative or absolute 2) collecting relevant information and 3) applying the standards to determine value, quality, utility, effectiveness, or significance (p. 5). Respectively, theoretical and field study research findings have indicated that evaluation enhances organizational learning (Atkinson, et al., 2005; Henry and Mark, 2003; Preskill, et al., 2003; Robson 1993; Sridharan, 2003; Worthen et al, 1997).

By the same token, language educators have currently witnessed growing developments in the accrual of an integrated language approach to learning and teaching (Short, 2006). Language skills are not only important for developing the communicative skills in the English language, but they also foster an integrated teaching of reading, writing, listening, speaking which still remains at the core of literacy development as well (Laine, 1997). Underlying this is the assumption that production skills (speaking/writing) and reception skills (listening/reading) go together, and they develop consecutively, simply because communicative interaction involves more than one language skill; in this vein, these language skills reinforce each other. Therefore, language instructors, pedagogically speaking, should teach students how to use the language, not just the forms. An Oxford $^{\circledR}$ series in language skills has been used as an innovative curricular provision to present the four skills of the English language at the English Department of the College of Languages and Translation, KKU; the series presents listening and speaking, reading comprehension, and writing in four levels, while in each course at each level, the Oxford ${ }^{\circledR}$ book in one skill seeks to present a curricular, integrated approach to all skills; i.e., in any Listening and Speaking book, the emphasis is on these two skills, yet, the course provides tasks and exercises covering reading and writing as well. The course books utilise a CLT approach blending both task-based and content-based tasks designed to promote a learner-centred approach. For example, in 
Academic Writing, writing skills can be achieved by such tasks as free writing, pre-teaching of vocabulary specific to a particular social context, selected use of vocabulary in cloze test exercises, process writing through learning to brain storm, mind-map, writing outlines and graphic organisers in pre-writing tasks, and reading comprehension to increase learners' awareness about a specific social event or function.

The purpose of this longitudinal study is to explore the effectiveness of the Integrated Language Skills Instruction approach in EFL college students. This study has been conducted for ...

1. Investigating the effectiveness of the language skills integration approach at college level;

2. Verifying findings from prior research indicating the effectiveness of the integrated approach, thus adding both to the theory and practice of integrated language teaching as proposed by Rebecca Oxford;

3. Utilising the implementational design of instruction and curriculum adaptation in this study for teaching language skills courses which constitute most of the basic four levels consortium;

4. Using this research findings in designing and implementing instructional and curricular plans not only for teaching English at college level, but also at pre-university levels.

\section{LITERATURE REVIEW}

The literature on ESL/EFL language skill development is vibrant with calls advocating the integrated approach to the study of language drawn from a skill-based language teaching approach (Arkin, 2010; Lynch, 1983; Moffett, 1983; Scarcella \& Oxford, 1992; Tierney and Pearson, 1994; Rosenblatt, 1994; Allred, 1994; Chamot, et al., 1999; Oxford \& Leaver, 1996; Flower and Hayes, 1994; Oxford, 2001; Tsung-Yuan \& Oxford, 2002).

However, there is little empirical testimony to evidence these claimed benefits of an integrated approach to language instruction. By definition, integrated language teaching here is meant to be a skill-based approach to teaching language skills all in one. Other definitions, not applicable to study, is that integrated language teaching refers to an approach in which content and language integrated learning (CLIL) bring together language teaching with the teaching of other subjects (Kleinsasser, 2013, p. 93). The integrated language skills approach is thought to be an effective strategy for whole language learning, promoting learning to be used meaningfully in real life contexts for communicative purposes (Scarcella \& Oxford, 1992; Oxford, 2001). In other words, this approach seeks to teach language as a means of communication to serve the purpose it was originally created for, which can be motivating and realistic as well (TsungYuan \& Oxford, 2002; Pennycook, 1989; Brown, 2001). The underlying tenet is that language is the medium of thought, feeling, and communication which enables one to develop self-awareness, to interact with others, and to learn (TsungYuan \& Oxford, 2002).

There are claims, however, that the integrated skills approach can be an efficient inducement to higher levels of motivation towards language learning in EFL students (Pennycook, 1989; Brown, 2001; Celce-Murcia, 2001; Oxford, 2001; Richard-Amato, 2003).

The traditional separation of language skills instruction with emphasis on particular skills and grammatical drills has brought into the mainstream underprepared students who are being given access to higher education through open admissions programmes since the 1970s all around the world (King, 1996). Though King's research is related to US college students, we can take his findings into account because his subjects were not only from the United States but from all over the world.

The segregation of the skills is not consistent with the nature of language development in the first language context. In the first language context all language skills are interrelated. The interrelatedness of the language skills can be deduced from observation of a child's development of oral and written language which follows the sequence of listening, speaking, reading, and writing. In this vein, Strang (1972) noted this sequence:

'Listening precedes speaking and reading. Children acquire their native tongue through listening to and imitating the speech of their parents. Speaking is basic to both reading and writing' (p. 291).

The recognition of this sequential growth identifies the language skills as being interwoven and interdependent. It also suggests that a problem in one language skill will usually carry over to another skill, while proficiency in one skill facilitates development of another skill (Strang, 1972).

However, there is always a hot debate whether L1 and L2 are learned in the same way or not. But the use of the integration of skills in L2 teaching as it happens in L1 "acquisition", using Krashen's term, is seldom criticized. As the same kind of human brain processes both L1 and L2, one can deduce the necessity of the interrelatedness of the language skills in an L2 classroom from a child's L1 development in his/her native environment (Alatis, 1981).

Early research findings (e.g. Strickland, 1964; Loban, 1963; Ruddell, 1966; Thomas, 1974; Cayer and Sacks, 1979) suggest that a student's ability to use the listening and speaking skills is closely related to the learner's ability to comprehend written language, and further deploy these skills to reading comprehension. Researchers in this area have concluded that an essential foundation for competence in reading and writing reflects a similar competence in oral language; Laine (1997) in an empirical research has remarked that "Oral language activities may help to develop students' reading, writing, and thinking strategies.

Recent empirical research (e.g. Al-Ghamari, 2004; Bose, 2003; Faydi, 2003; Hefferman, 2006) also indicated the significance of integrated skill presentation for improved language learning outcomes, especially the integration of writing skills with other language skills such as reading, listening, speaking and pronunciation. 
More specifically, in teaching writing, research suggests that segregated skill teaching, the lack of authentic communication that typically exists in EFL contexts, and difficulties with sequencing teaching-learning activities combine to hinder the development of writing skills (Hao \& Sivell, 2002). Relevantly, the theoretical work of Rosenblatt (1994), Moffett (1983), Flower and Hayes (1994), and Vyqotsky (1986) and the pedagogical work of Atwell (1987) and Elbow (1986), and Bartholomae and Petrosky (1986) assert that all language skills in addition to thinking skills are all involved while learners activate their schemata (boxes of information stored in their memories) during the process of meaning-making when they read or write their own and others' texts (See Vygotsky, 1986). These authors showed that all the skills of language such as reading and writing cannot be considered as separate entities but should be integrated to ease the communicative process.

Segregated skill teaching emanates from the philosophy that sees successful second language learning as a process departing from content learning (Oxford, 2001); however, this philosophy is very much emphasised in the traditional ESL/EFL methodology and curriculum provisioning (Mohan, 1986; Oxford, 2001; Tsung-Yuan \& Oxford, 2002). Oxford (2001) explains that this philosophy is easier in practice, yet ineffective to warrant later whole language development for communicative purposes.

She further rebuts segregation claims suggesting that such a methodology is deficient and inadequate for "later success in academic communication, career-related language use, or everyday interaction in the language" (Oxford, 2001, p.2).

Like Oxford (2001), Hinkel (2006), in the EFL context, and Berninger (2000) and Shanahan (2006), in language learning in general, concluded that the four skills of listening, speaking, reading and writing should not be treated as separate and dissimilar cognitive domains because each of these skills complements the others and helps them to grow.

Given that the integration approach involves either using a task-based instruction approach or a content-based instruction approach, or a hybrid amalgam of both (Oxford, 2001), writing can be developed integratedly with other skills for whole language development and for purposes of communicative language teaching. Research fosters the use of writing and reading journals or logs 'a method not only of integrating reading and writing but also for fostering reading and writing development' (Sehlaoui, 2001). In the Oxford ${ }^{\circledR}$ series, it is strongly recommended for students to use writing journals and reading journals as well as external resources (e.g. newspapers, books, the Internet, etc.) to supplement the writing / reading lessons. So is the case in the new Oxford series of Well Read, Open Form, and Keep Writing - a new series of integrated Listening and Speaking, writing and reading courses, in which the four language skills are integrated in the lessons to integrally supplement listening and speaking skills development.

\section{ReSEARCH Methodology}

\section{Participants}

The population of the study consists of male students learning English at the College of Languages and Translation, KKU, averagely aged 18-20 years in the academic year 2011-2012. All participants in both the control and the experimental group are currently enrolled in the Oxford ${ }^{\circledR}$ course-sets in Listening and Speaking, Reading Comprehension, and Writing (Open Forum 3, Well Read 3 - Effective Academic Writing2).

Participants have been assigned to an instructor and a course section in a random manner through the regular university registration process. Since different instructors are expected to participate in this study, it is necessary to test for 'instructor variables' (such as teaching style and personality), thus determining if an individual instructor produced a direct or interactive effect on the dependent measures.

Design

This study involves an analysis of the performance of two groups of students. The experimental group $(n=27$ students), who are currently being taught the language skills in an integrated approach (Course code 212 ENG-3 Section 2327 in the second semester of the academic year 2011/2012). The control group $(n=25$, Course code 212 ENG-3 - Section 2328 in the second semester of the academic year 2011/2012) are to complete the same skills courses with no particular emphasis on skill integration.

\section{Hypotheses}

This study will be designed to test the following null hypotheses at the 0.05 level of significance:

1) There are no statistically significant differences between pre-test measures of the language skills of experimental students and control students.

2) There are no statistically significant differences between levels of students' performance in language skills due to the effects of individual instructors.

3) There are no statistically significant differences between post-test measures of reading comprehension and vocabulary development of experimental students and control students.

4) There are no statistically significant differences between measures of listening and speaking of experimental students and control students.

5) There are no statistically significant differences between the language skills final examination scores for experimental students and control students.

Research Groups 
Experimental and control groups, assuring that all extraneous variables are kept constant, have been achieved through randomization. To assure that the characteristics of the sample members are almost similar, participants will be randomly assigned to experimental and control groups.

\section{Instrumentation}

The researcher and other four instructors who are expected to participate in conducting this study will utilise assessments of student performance in the areas of writing (descriptions, paragraphs, descriptive, narrative, and analytical essay writing), reading comprehension, and vocabulary building. To measure overall student performance in the entire language skills, final skills exams scores will be used. These tests have been constructed and validated by the members of the department, all having been standardised and piloted in the first semester.

\section{Statistical Treatment}

To verify that the control and experimental groups are representative of the same sample population (hypothesis one), a two-tailed $t$ test will be computed based on their skills test scores obtained prior to this present experiment from their immediately previous writing, reading and comprehension, and listening and speaking courses. In testing for all other hypotheses, it is important to consider the effects that a given teaching style will potentially have on student performance.

SPSS vers 16.00 was used to analyse data gleaned from this investigation. ANOVA and t-tests are the main statistical analysis methods that are likely to be used in this study.

\section{DATa ANALYSIS AND RESUlts}

\section{Descriptive analysis}

For data analysis, SPSS (Ver. 14) and Excel (Ver. 2007) were employed in the statistical study. Table 1 below demonstrates the descriptive statistics of the pretest and posttest comparisons of the performance of both experimental and control groups. To construct two homogeneous groups for study, the student's participants' scores in listening \& speaking, writing and reading comprehension.

TABLE 1

DESCRIPTIVE STATISTICS OF RESEARCH GROUPS IN ALL SKILLS

\begin{tabular}{|c|c|c|c|c|c|}
\hline Group & & Listening & Speaking & Reading & Writing \\
\hline \multirow{5}{*}{$\begin{array}{l}\text { Experimental group } \\
\text { Pretest }\end{array}$} & Mean & 22.15 & 21.33 & 22.11 & 23.11 \\
\hline & $\mathrm{N}$ & 27 & 27 & 27 & 27 \\
\hline & Std. Deviation & 3.110 & 3.026 & 3.203 & 2.900 \\
\hline & Minimum & 18 & 17 & 15 & 17 \\
\hline & Maximum & 29 & 28 & 28 & 29 \\
\hline \multirow[t]{5}{*}{ Control group Pretest } & Mean & 23.04 & 22.12 & 21.32 & 23.80 \\
\hline & $\mathrm{N}$ & 25 & 25 & 25 & 25 \\
\hline & Std. Deviation & 3.089 & 3.333 & 3.172 & 2.598 \\
\hline & Minimum & 19 & 17 & 15 & 17 \\
\hline & Maximum & 30 & 28 & 25 & 29 \\
\hline \multirow{5}{*}{$\begin{array}{l}\text { Experimental group } \\
\text { Posttest }\end{array}$} & Mean & 74.11 & 87.07 & 69.07 & 84.96 \\
\hline & $\mathrm{N}$ & 27 & 27 & 27 & 27 \\
\hline & Std. Deviation & 4.255 & 1.999 & 3.782 & 1.829 \\
\hline & Minimum & 66 & 83 & 62 & 82 \\
\hline & Maximum & 81 & 90 & 75 & 89 \\
\hline \multirow[t]{5}{*}{ Control group Posttest } & Mean & 69.00 & 78.84 & 64.16 & 71.00 \\
\hline & $\mathrm{N}$ & 25 & 25 & 25 & 25 \\
\hline & Std. Deviation & 4.291 & 2.173 & 4.497 & 3.786 \\
\hline & Minimum & 60 & 75 & 57 & 64 \\
\hline & Maximum & 78 & 84 & 75 & 79 \\
\hline
\end{tabular}

Data were further gleaned from pretesting and post-testing, and then analysed using t-tests.

\section{Hypothesis I: Group Equivalence}

To test the first null hypothesis in order to make sure that they began the experiment at comparatively similar levels of skills, a t-test was calculated to confirm group equivalence before the relevant treatments were delivered to the respective groups; the obtained t-values and their significance levels are shown in (Table 2) below. 
TABLE 2

Group EQuivalence as Measured by All SKILls PRETESTING

\begin{tabular}{|c|c|c|c|c|c|c|}
\hline Skills & Group & $\mathbf{N}$ & Mean & SD & t-value & Sig. \\
\hline \multirow[t]{2}{*}{ Listening } & Experimental group & 27 & 22.15 & 3.110 & \multirow{2}{*}{-1.037} & \multirow{2}{*}{.305} \\
\hline & Control group & 25 & 23.04 & 3.089 & & \\
\hline \multirow[t]{2}{*}{ Speaking } & Experimental group & 27 & 21.33 & 3.026 & \multirow{2}{*}{-.892} & \multirow{2}{*}{.377} \\
\hline & Control group & 25 & 22.12 & 3.333 & & \\
\hline \multirow[t]{2}{*}{ Reading } & Experimental group & 27 & 22.11 & 3.203 & \multirow{2}{*}{.894} & \multirow{2}{*}{.376} \\
\hline & Control group & 25 & 21.32 & 3.172 & & \\
\hline \multirow[t]{2}{*}{ Writing } & Experimental group & 27 & 23.11 & 2.900 & \multirow{2}{*}{-.900} & \multirow{2}{*}{.373} \\
\hline & Control group & 25 & 23.80 & 2.598 & & \\
\hline
\end{tabular}

The t-tests have been employed to compare the means of two groups. Considering the results of the table 3., the value As shown in Table 2 above, the independent samples t-test technique was applied to the mean.

Experimental group and Control group scores for test structure and written knowledge of the learners at beginning of the research in order to examine the differences in Listening.

T-test results for both the experimental group and control group showed that there are no significant differences between the students in both groups $[\mathrm{t}(50)=-1.037 \mathrm{p}>.05]$ in Listening, $[\mathrm{t}(50)=-.892 \mathrm{p}>.05]$ in Speaking, [ $\mathrm{t}(50)$ $=.894 \mathrm{p}>.05]$ in Reading, $[\mathrm{t}(50)=-.900 \mathrm{p}<.05]$ in Writing. This asserts that the experimental and control groups were equal on pretesting, thereby ascertaining to group equivalence before any treatments were given to the students in these groups (See Figure 1 below).

Figure 2b: Writing pretesting scores for experimental and control groups

In addition, Table 2 above demonstrates that there were no statistically significant differences between the experimental and control groups on pre-testing. Thus, the first hypothesis was verified, and group equivalence was confirmed as it is shown in Figure 3 below.

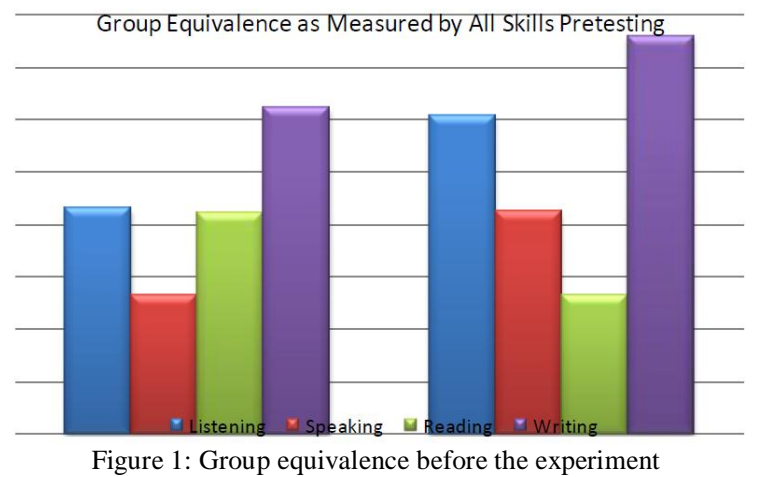

The other hypotheses examined are related to the study variables preset to measure students' proficiency in all skills of listening, speaking, reading comprehension, and writing that may have resulted from integrated skills instruction. Post-treatment measures were employed after all students, in both the experimental and the control groups, had completed the Oxford ${ }^{\circledR}$ courses with an integrated skills pedagogy and the Oxford ${ }^{\circledR}$ courses with no work purposefully done towards skill integration respectively.

\section{Hypothesis II: Pre/Post-treatment Comparisons}

The data presented in (Table 3) show an improvement on pre-test/post-test comparisons for all skills; as the t-values indicate, there is a significant difference between experimental and control students $(\mathrm{p}=0.01)$ to the good of the experimental class in all skills following exposure to integrated skills instruction. The second hypothesis is therefore confirmed.

TABLE 3

Pretesting/Posttesting Comparisons of ExPerimental Group Performances on All Skills

\begin{tabular}{|c|c|c|c|c|c|c|}
\hline Skills & Group & $\mathbf{N}$ & Mean & SD & $t$-value & Sig. \\
\hline \multirow[t]{2}{*}{ Listening } & Experimental group & 27 & 74.11 & 4.255 & \multirow{2}{*}{4.310} & \multirow{2}{*}{.000} \\
\hline & Control group & 25 & 69.00 & 4.291 & & \\
\hline \multirow[t]{2}{*}{ Speaking } & Experimental group & 27 & 87.07 & 1.999 & \multirow{2}{*}{14.233} & \multirow{2}{*}{.000} \\
\hline & Control group & 25 & 78.84 & 2.173 & & \\
\hline \multirow[t]{2}{*}{ Reading } & Experimental group & 27 & 69.07 & 3.782 & \multirow{2}{*}{4.276} & \multirow{2}{*}{.000} \\
\hline & Control group & 25 & 64.16 & 4.497 & & \\
\hline \multirow[t]{2}{*}{ Writing } & Experimental group & 27 & 84.96 & 1.829 & \multirow{2}{*}{17.135} & \multirow{2}{*}{.000} \\
\hline & Control group & 25 & 71.00 & 3.786 & & \\
\hline
\end{tabular}

The researchers used t-tests to compare the means of two groups. Considering the results of the table 2., the value As shown in Table3, the independent samples t-test technique was applied to the mean. Experimental group and Control 
group scores for test structure and written knowledge of the learners at beginning of the research in order to examine the differences in Listening.

According to the result of the t-test made between the Experimental group and Control group to whom traditional teaching method was applied, there is a statistically significant difference of $[\mathrm{t}(50)=4.310 \mathrm{p}<.05]$ in Listening, $[\mathrm{t}(50)$ $=14.233 \mathrm{p}<.05]$ in Speaking, $[\mathrm{t}(50)=4.276 \mathrm{p}<.05]$ in Reading, $[\mathrm{t}(50)=17.135 \mathrm{p}<.05]$ in Writing . This confirms that there are statistically significant differences between the mean scores of students in all skills in the experimental and control groups on protesting alike which ensures group equivalence.

Pretesting/Post testing Comparisons of Control Group Performances on All Skills

Based on the results in the above table, the hypothesis suggesting that there are significant differences between both research groups on all skills in favour of the treatment group has been verified as well; this finding is commensurate with prior research findings indicating that integrated skills teaching is effective in improving language skills improvement (O'Day, 2002; Flora, 1995; King, 1996; Lynch, 1983; Scarcella \& Oxford, 1992; Rosenblatt, 1994; Allred, 1994; Oxford \& Leaver, 1996; Flower and Hayes, 1994; Oxford, 2001).

TABLE 4

ANALYSIS OF PRE-TEST AND POST-TEST SCORES OF THE EXPERIMENTAL GROUP

\begin{tabular}{|c|c|c|c|c|c|c|}
\hline \multicolumn{2}{|c|}{ Experimental Group } & Mean & $\mathrm{N}$ & SD & t-value & Sig. \\
\hline \multirow[t]{2}{*}{ Listening } & Pretest & 74.11 & 27 & 4.255 & \multirow{2}{*}{42.149} & \multirow{2}{*}{.000} \\
\hline & Posttest & 22.1481 & 27 & 3.10958 & & \\
\hline \multirow[t]{2}{*}{ Speaking } & Pretest & 87.07 & 27 & 1.999 & \multirow{2}{*}{95.712} & \multirow{2}{*}{.000} \\
\hline & Posttest & 21.3333 & 27 & 3.02553 & & \\
\hline \multirow[t]{2}{*}{ Reading } & Pretest & 69.07 & 27 & 3.782 & \multirow{2}{*}{53.400} & \multirow{2}{*}{.000} \\
\hline & Posttest & 22.1111 & 27 & 3.20256 & & \\
\hline \multirow[t]{2}{*}{ Writing } & Pretest & 84.96 & 27 & 1.829 & \multirow{2}{*}{123.736} & \multirow{2}{*}{.000} \\
\hline & Posttest & 23.1111 & 27 & 2.90004 & & \\
\hline
\end{tabular}

In addition, t-test results of pre-test and post-test scores of the experimental group in language skills revealed statistically significant differences $[\mathrm{t}(26)=42.149 \mathrm{p}<.05]$ in Listening, $[\mathrm{t}(26)=95.712 \mathrm{p}<.05]$ in Speaking, [ $\mathrm{t}(26)=$ $53.400 \mathrm{p}<.05]$ in Reading, $[\mathrm{t}(26)=123.736 \mathrm{p}<.05]$ in Writing between pretesting and post-testing of the experimental students to the good of post-testing.

TABLE 5

ANALYSIS OF PRE-TEST AND POST-TEST SCORES OF THE CONTROL GROUP

\begin{tabular}{|c|c|c|c|c|c|c|}
\hline \multicolumn{2}{|c|}{ control Group } & Mean & $\mathrm{N}$ & Std. Deviation & t-value & Sig. \\
\hline \multirow[t]{2}{*}{ Listening } & Pretest & 69.0000 & 25 & 4.29146 & \multirow{2}{*}{41.986} & \multirow{2}{*}{.000} \\
\hline & Posttest & 23.0400 & 25 & 3.08869 & & \\
\hline \multirow[t]{2}{*}{ Speaking } & Pretest & 78.8400 & 25 & 2.17332 & \multirow{2}{*}{66.765} & \multirow{2}{*}{.000} \\
\hline & Posttest & 22.1200 & 25 & 3.33317 & & \\
\hline \multirow[t]{2}{*}{ Reading } & Pretest & 64.1600 & 25 & 4.49704 & \multirow{2}{*}{37.589} & \multirow{2}{*}{.000} \\
\hline & Posttest & 21.3200 & 25 & 3.17175 & & \\
\hline \multirow[t]{2}{*}{ Writing } & Pretest & 71.0000 & 25 & 3.78594 & \multirow{2}{*}{63.644} & \multirow{2}{*}{.000} \\
\hline & Posttest & 23.8000 & 25 & 2.59808 & & \\
\hline
\end{tabular}

Furthermore, t-test results of pre-test and post-test scores of the control group in language skills showed meaningful differences between the assessments: $[\mathrm{t}(24)=41.986 \mathrm{p}<.05]$ in Listening, $[\mathrm{t}(24)=66.765 \mathrm{p}<.05]$ in Speaking, [ $\mathrm{t}(24)$ $=37.589 \mathrm{p}<.05]$ in Reading, $[\mathrm{t}(24)=63.644 \mathrm{p}<.05]$ in Writing performances of the students.

\section{Hypothesis III: Gains in Skill Development}

For differences in performance over time between the two groups, the researcher employed gain scores and the Paired Samples Statistics.

TABLE 6

ANALYSIS OF FOLLOW-UP TEST AND POSTTEST SCORES OF THE EXPERIMENTAL GROUP

\begin{tabular}{|c|c|c|c|c|c|c|}
\hline \multicolumn{2}{|c|}{ Experimental Group } & Mean & $\mathrm{N}$ & Std. Deviation & t-value & Sig. \\
\hline \multirow[t]{2}{*}{ Listening } & Follow-up test & 48.9630 & 27 & 5.72768 & \multirow{2}{*}{18.275} & \multirow{2}{*}{.000} \\
\hline & Posttest & 74.11 & 27 & 4.255 & & \\
\hline \multirow[t]{2}{*}{ Speaking } & Follow-up test & 61.8519 & 27 & 3.33632 & \multirow{2}{*}{37.088} & \multirow{2}{*}{.000} \\
\hline & Posttest & 87.07 & 27 & 1.999 & & \\
\hline \multirow[t]{2}{*}{ Reading } & Follow-up test & 46.7778 & 27 & 3.17845 & \multirow{2}{*}{21.722} & \multirow{2}{*}{.000} \\
\hline & Posttest & 69.07 & 27 & 3.782 & & \\
\hline \multirow[t]{2}{*}{ Writing } & Follow-up test & 59.0000 & 25 & 2.12132 & \multirow{2}{*}{13.558} & \multirow{2}{*}{.000} \\
\hline & Posttest & 71.0000 & 25 & 3.78594 & & \\
\hline
\end{tabular}

For differences in performance over time between the two groups, the researcher employed gain scores and paired samples statistics. 
TABLE 7

ANALYSIS OF FOLLOW-UP TEST AND POSTTEST SCORES OF THE EXPERIMENTAL GROUP

\begin{tabular}{|c|c|c|c|c|c|c|}
\hline \multicolumn{2}{|c|}{ Experimental Group } & Mean & $\mathrm{N}$ & Std. Deviation & t-value & Sig. \\
\hline \multirow[t]{2}{*}{ Listening } & Follow-up test & 48.9630 & 27 & 5.72768 & \multirow{2}{*}{18.275} & \multirow{2}{*}{.000} \\
\hline & Posttest & 74.11 & 27 & 4.255 & & \\
\hline \multirow[t]{2}{*}{ Speaking } & Follow-up test & 61.8519 & 27 & 3.33632 & \multirow{2}{*}{37.088} & \multirow{2}{*}{.000} \\
\hline & Follow-up test & 87.07 & 27 & 1.999 & & \\
\hline \multirow[t]{2}{*}{ Reading } & Posttest & 46.7778 & 27 & 3.17845 & \multirow{2}{*}{21.722} & \multirow{2}{*}{.000} \\
\hline & Follow-up test & 69.07 & 27 & 3.782 & & \\
\hline \multirow[t]{2}{*}{ Writing } & Follow-up test & 59.0000 & 25 & 2.12132 & \multirow{2}{*}{13.558} & \multirow{2}{*}{.000} \\
\hline & Posttest & 71.0000 & 25 & 3.78594 & & \\
\hline
\end{tabular}

According to the t-test result made between follow- up testing and post-testing scores of the experimental group in language skills, it was seen that a meaningful difference existed $[\mathrm{t}(26)=18.275 \mathrm{p}<.05]$ in Listening, $[\mathrm{t}(26)=37.088 \mathrm{p}$ $<.05]$ in Speaking, $[\mathrm{t}(26)=21.722 \mathrm{p}<.05]$ in Reading, $[\mathrm{t}(26)=13.558 \mathrm{p}<.05]$ in Writing.

TABLE 8

ANALYSIS OF FOLLOW-UP TEST AND POSTTEST SCORES OF THE CONTROL GROUP

\begin{tabular}{|c|c|c|c|c|c|c|}
\hline Experimental Group & & Mean & $\mathrm{N}$ & Std. Deviation & t-value & Sig. \\
\hline \multirow[t]{2}{*}{ Listening } & Follow-up test & 69.0000 & 25 & 4.29146 & \multirow{2}{*}{17.087} & \multirow{2}{*}{.000} \\
\hline & Posttest & 46.4800 & 25 & 3.50143 & & \\
\hline \multirow[t]{2}{*}{ Speaking } & Follow-up test & 78.8400 & 25 & 2.17332 & \multirow{2}{*}{25.131} & \multirow{2}{*}{.000} \\
\hline & Follow-up test & 57.6800 & 25 & 3.69369 & & \\
\hline \multirow[t]{2}{*}{ Reading } & Posttest & 64.1600 & 25 & 4.49704 & \multirow{2}{*}{17.329} & \multirow{2}{*}{.000} \\
\hline & Follow-up test & 44.7600 & 25 & 3.03150 & & \\
\hline \multirow[t]{2}{*}{ Writing } & Follow-up test & 71.0000 & 25 & 3.78594 & \multirow{2}{*}{19.250} & \multirow{2}{*}{.000} \\
\hline & Posttest & 52.9600 & 25 & 2.47454 & & \\
\hline
\end{tabular}

According to the t-test result of follow-up testing and post-testing scores of the control group, it was seen that a meaningful difference existed $[\mathrm{t}(24)=17.087 \mathrm{p}<.05]$ in Listening, $[\mathrm{t}(24)=25.131 \mathrm{p}<.05]$ in Speaking, $[\mathrm{t}(24)=$ $17.329 \mathrm{p}<.05]$ in Reading, and $[\mathrm{t}(24)=19.250 \mathrm{p}<.05]$ in the writing performances of the students.

TABLE 9

ANALYSIS OF FOLLOW-UP AND POSTTEST SCORES OF THE EXPERIMENTAL \& CONTROL GROUPS

\begin{tabular}{|c|c|c|c|c|c|c|}
\hline \multicolumn{2}{|l|}{ Skills } & Mean & $\mathrm{N}$ & Std. Deviation & t-value & Sig. \\
\hline \multirow[t]{2}{*}{ Listening } & Ex & 48.9630 & 27 & 5.72768 & \multirow{2}{*}{1.868} & \multirow{2}{*}{.068} \\
\hline & Ctrl & 46.4800 & 25 & 3.50143 & & \\
\hline \multirow[t]{2}{*}{ Speaking } & Ex & 61.8519 & 27 & 3.33632 & \multirow{2}{*}{4.279} & \multirow{2}{*}{.000} \\
\hline & Ctrl & 57.6800 & 25 & 3.69369 & & \\
\hline \multirow[t]{2}{*}{ Reading } & Ex & 46.7778 & 27 & 3.17845 & \multirow{2}{*}{2.338} & \multirow{2}{*}{.023} \\
\hline & Ctrl & 44.7600 & 25 & 3.03150 & & \\
\hline \multirow[t]{2}{*}{ Writing } & Ex & 59.5185 & 27 & 2.81985 & \multirow{2}{*}{8.884} & \multirow{2}{*}{.000} \\
\hline & Ctrl & 52.9600 & 25 & 2.47454 & & \\
\hline
\end{tabular}

Data in Table 9 above shows a significant increase $(\mathrm{p}<.01)$ in the experimental group's gain scores as compared with their peers in the control group to the good of experimental students. This disconfirms the third hypothesis which indicates that there are no statistically significant differences between post-test measures of reading comprehension and vocabulary development of experimental students and control students.

\section{Results from the Qualitative Data Analysis}

\section{A. Survey Results}

According to the results of the quantitative data which shows a significant increase $(\mathrm{p}<.01)$ in the experimental group's gain scores in comparison with those of the control group's, it is clear that the integrated language skills teaching yielded better results. Although both the groups showed improvement suggesting that the contents of the course are appropriate, yet the overall differences across all skills as shown in tables (8) and (9) indicate that a significant difference can be achieved by simply shifting the emphasis from teaching language skills in isolation to teaching them in an integrative fashion. Moreover, the most significant improvement occurred to students' writing skill, chiefly because the researcher's focus was mainly on teaching writing skill and other skills like reading, speaking and listening were utilised to integrate writing skill. Secondly, the two other teachers involved in the study also integrated writing skill in to their respective skills of listening, speaking and reading. This accounts for the marked difference in the improvement of writing.

The questionnaires have been used to reveal the trends and perceptions of both the teachers and students. The emerging themes relate to the quality of the Writing Skill course book, both content and 'teachability'-wise. The teachers involved in the study together with other teachers who taught the new Oxford series at this level (26 in number) filled the questionnaire (See Table 10 and Figure 2 below). 
TABLE 10

FACULTY MEMBERS' FREQUENCIES AND PERCENTAGES OF PARTICIPANTS

\begin{tabular}{|c|c|c|c|}
\hline & & Frequency & Percent \\
\hline \multirow[t]{3}{*}{ Faculty members } & Assistant Professors & 18 & 69.2 \\
\hline & Lecturers & 8 & 30.8 \\
\hline & Total & 26 & 100.0 \\
\hline
\end{tabular}

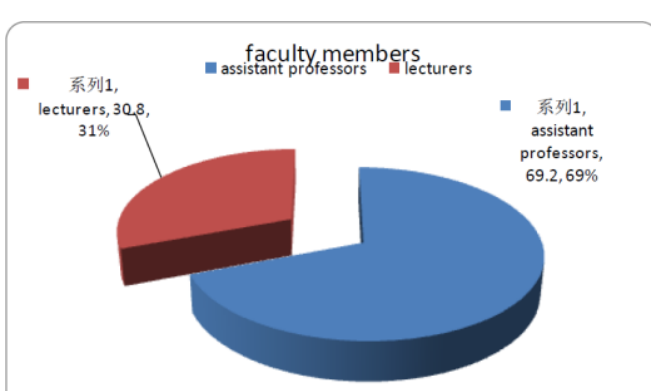

Figure 2: Distribution of survey informants

TABLE 11

MEANS AND SD OF TEACHERS' RESPONSES ON THE TEACHERS' QUESTIONNAIRE

\begin{tabular}{|c|c|c|}
\hline & Mean & Std. Deviation \\
\hline Size and Volume & 4.58 & 0.504 \\
\hline Attractive Outlook & 4.65 & 0.745 \\
\hline Quality of editing & 4.5 & 0.707 \\
\hline Appearance of the Book: & 4.58 & 0.65 \\
\hline Availability / Clarity of the overall aims and objectives of the entire book & 5 & 0 \\
\hline Availability / Clarity of the aims and objectives of the individual chapters & 5 & 0 \\
\hline Organization and sequencing of chapters & 4.81 & 0.402 \\
\hline Organization and sequencing of activities and exercises & 3.77 & 0.815 \\
\hline Learner centered & 4.46 & 0.647 \\
\hline Teacher centered & 4.65 & 0.745 \\
\hline Text centered & 5 & 0 \\
\hline Overall Approach of the book & 4.70 & 0.46 \\
\hline Availability of Methodology & 5 & 0 \\
\hline Availability of Classroom Strategies and Techniques & 3.58 & 0.758 \\
\hline Availability of Language items for course objectives & 4.12 & 0.952 \\
\hline Level of interest in given passages/topics, etc. & 4.19 & 0.981 \\
\hline Variety in Activities and exercises & 2.85 & 1.008 \\
\hline Integrated activities & 4.85 & 0.368 \\
\hline Suitability of Exercises and activities & 4.46 & 0.647 \\
\hline Availability of graphs, charts, tables, etc. & 4.46 & 0.647 \\
\hline Availability of Audio-Visual Aids & 4.46 & 0.647 \\
\hline Quality of Audio-Visual Aids, (If any) & 4.58 & 0.504 \\
\hline Utility of these audio-visual aids & 1.88 & 0.653 \\
\hline Effectiveness of these audio-visual aids & 5 & 0 \\
\hline the book on the whole & 1.92 & 0.688 \\
\hline the passages / texts in the book & 1.46 & 0.647 \\
\hline activities and exercises in the book & 1.04 & 0.196 \\
\hline Language learning Strategies in the book & 4.62 & 0.637 \\
\hline & 2.26 & 0.54 \\
\hline Scope for supplementary materials & 4.65 & 0.689 \\
\hline Scope for Material adaptation (simplification, etc) & 4.73 & 0.533 \\
\hline Scope for Learners' participation & 4.73 & 0.533 \\
\hline Scope for Learners' Talk time & 4.65 & 0.629 \\
\hline Expected Teachers' Talk time & 4.73 & 0.452 \\
\hline the language skills / language functions & 4.73 & 0.533 \\
\hline the language learning strategies & 2.73 & 0.919 \\
\hline the language items & 4.19 & 0.981 \\
\hline the chapters & 4.5 & 0.648 \\
\hline Overall 'Teachability' of & 4.04 & 0.77 \\
\hline the language skills / language functions & 2.73 & 0.919 \\
\hline the language learning strategies & 4.5769 & 0.50383 \\
\hline the language items & 4.5 & 0.5831 \\
\hline the chapters & 1.7308 & 0.66679 \\
\hline Overall 'Learnability' of: & 3.38 & 0.67 \\
\hline
\end{tabular}


As it appears from Table 11, teachers involved were satisfied fully with the methodology, approach, organization, sequencing of chapters, effectiveness in terms of teaching the contents and cultural relevance of the book.

\section{B. Interview Analysis: Highlights}

Interviewed teachers have given their their reasons for choosing the instructional techniques that supported holistic, integrated language teaching. The interviewees have retrospectively spelt out their beliefs and assumptions that underlie integrated language instruction. According to interviewees, beliefs and tenets that that support integrated literacy instruction utilizes portions of listening, speaking, reading and writing discourse. Integrated language pedagogy is, and can be done through utilizing a variety of formal and informal methods in both structured and unstructured modes; thus, it is developmental, holistic, and is grounded in repetitions and patterns. Below are some excerpts of the responses of the interviewed teachers verbatim:

Integrated Literacy Instruction utilizes integrative portions of listening, speaking, reading and writing pieces of discourse:

Teacher 1: In language development we promote listening, speaking, reading and writing and all are equally important.

Teacher 2: We don't teach receptive skills first, then speaking and writing after that. We involve the students in listening, speaking, reading and writing, we just move from the simple to the complex.

Literacy instruction is structured and unstructured

Teacher 1: We believe in structured and unstructured curriculum. Depending on the readiness or maturity of the group.

Teacher 2: We follow our planning diaries and lesson plans, but sometimes we are a bit more relaxed.

Literacy instruction is developmental

Teacher 1: We need to give enough time to prepare the ground for the process to become a skill.

Teacher 2: Students are thinking in their mother tongue, so I consider this when I decide whether to repeat the lesson or go on.

\section{Literacy instruction is holistic}

Teacher 1: We believe in the holistic approach. You will see that as we go along we have grammar and structure exercises, but also time for dialogue that will be useful in their lives and natural conversations.

Teacher 2: We use a holistic approach for the overall development of a child. Creative activities and cultural activities.

We have a holistic approach. The Oxford ${ }^{\circledR}$ series promotes speaking and listening together with reading, more significantly. The Academic Writing book address the language skills, but has many activities for writing. Free writing, well, a bit of free writing.

Literacy instruction is integrated

Teacher 1: Our philosophy includes integration of reading with writing, listening with speaking.

Teacher 2: There are varied exercises focusing on drawing links between the different threads of language skills in a sequence that is mostly likely inducing to or guaranteeing integration.

Literacy instruction uses repetition

Teacher 1: Listening and Speaking Oxford ${ }^{\circledR}$ courses, such as Open Forum have planned and repeated listening to stories, music, sounds. And vocabulary and phrases. In the writing book, there are repetitive exercises aiming at linking language skills and drilling kill patterns.

Teacher 2: Planned and repeated vocabulary is built up in order to enable them to speak in sentences. This improves fluency in speech, using words to form sentences and patterns of sentences.

\section{Literacy instruction uses patterns}

Teacher 1: In writing classes, sentence patterns and paragraph patterns are out there. Before students are asked to speak or present their writings, the teacher demonstrates the sentence pattern several times.

Teacher 2: We use patterns and repetition then students learn with ease and confidence.

It is worth noting that while teachers in the interview identified their teaching as 'holistic', it appeared this had a different meaning from what is often referred to as 'holistic'. The constructivist perspective about holistic teaching indicates that students' engagement in a process of learning depends on their background, interest, and abilities (Stainback \& Stainbeck, 1992). This perspective does not seem to be the point of reference for what they were calling "holistic." Occasionally, "holistic" is used to describe instruction for special education that recognizes multi-modals of learning or focuses on multi-sensory techniques (Daniels, 1999; Oxford, 2001).

\section{Diary Analysis: Highlights}

The journals that instructors kept indicated in order to help integrate the language skills and teach language holistically, teachers themselves should model the paradigm for their students, sharing their practices and products publicly in the classroom so that students can experience the thinking and actions of a particular writer, the teacher being a model in this context. One teacher wrote in his diary:

"Drawing on my own experiences as a writer means putting myself on the line, sharing what it is like to go through some of the same struggles and successes the students experience." 
Another teacher wrote:

“. . I learned that I only have to write a little bit better than my students for them to learn from my demonstrations ... I teach them that writing is important, but it is equally important for them that they become competent presenters of their writings - this requires, in reality, developing their speaking and reading skills diametrically.."

Given the importance that these teachers place on using their own literacy practices as teaching models, and a holistic development of the language skills, one might infer that it is important for new teachers in the department, who have not been familiar with the Oxford ${ }^{\circledR}$ series, to receive the same sort of modeling while they present the individual courses of Oxford $^{\circledR}$, thus missing a lot in achieving integration of skills in their teaching. In real practice in the classroom, there appears to be scant evidence that this occurs.

\section{DISCUSSION}

The gains of the Integrated Language Skills group in both writing and in the interrelated skills of listening comprehension, speaking and reading comprehension may be attributed to the emphasis placed on presenting the writing skills in integration with other skills and sub skills. The experimental writing course was instructionally designed to provide ample time and integration effort for instructional activities in the various areas of language skills while approaching these skills in an integrated manner in. This finding is compatible with other observations and research findings of some authors and critics (e.g., Oxford, 2001; Scarcella \& Oxford, 1992; King, 1996; Landberg, 1993; Laine, 1997; Allred, 1994; Flora, 1997; O'Day, 2002; Hefferman, 2006). The results of this study demonstrate these views. The Integrated Language Skills students, who were found to be deficient in communications skills before the initiation of the study, were able to develop their skills in the most complex area of language - writing - while working on other skills areas. As has been earlier noted, reading and listening before writing all helped to brush up on the skills and linguistic as well as real world knowledge of the students which helped in the overall development of their writing skills.

In other words, writing skill, which is more demanding than other language skills, developed more in the experimental treatment group than the control one because integrated skills teaching helped and supported overall language development for communicative purposes - e.g. the integrated instruction in vocabulary, grammar, reading comprehension, listening and speaking all contributed to induced language development by helping learners to use vocabulary well in context, use ideas from reading and listening texts, etc. The use of authentic communication, sequenced teaching-learning activities tasks integrating all skills as being all equally important, use of content-based material, especially in reading before writing, classroom and peer discussions, the use of writing and reading journals, and the use of student-tape recording as well as supplementary cassette and video segments accompanying the course all contributed to the improvement of all skills in the experimental group participants. In this vein this innovation clearly supports Breen and Candlin's views on the issue of inter-relatedness of skills development and curriculum purposes. "Just as no single communication ability can develop independently of other abilities, so the development of one skill may well depend on the appropriate development of other skills ... just as a refinement of the skill of reading, for example, will contribute to the development of speaking and vice-versa." (Breen \& Candlin, p 15). This confirms previous research findings and extrapolations in relevant literature on the topic of integrated skills teaching in foreign/second language teaching (Sehlaoui, 2001; Hao \& Sivell, 2002; Heffernan, 2006; Al-Ghamari, 2004; Oxford, 2001; Faydi, 2003; Bose, 2003).

The philosophy that underpins integrated skills teaching is also reflected in the ideas in Graves (2001, p 184) discussion of a 'four-skills based approach to syllabus design' to build the proficiency level of the learners. This according to him can be best achieved by teachers who 'find ways to integrate them'. The present study was a step in this direction and demonstrated that the students proficiency level in the experimental group improved significantly by the innovative use of skills' integration.

Finally, as pointed out in the aim of the study, this was meant to be a "formative, evaluative research" which "is designed to provide information that may be used for the basis for future planning and action". (Rea-Dickens \& Germaine, 2001, p 254). Therefore, the findings that integrated skills teaching improved students' overall communication proficiency in all the skills, especially writing, makes this research a valuable reference document. It may influence some policy decision in favour of a shift towards teaching language skills in an integrated way. It should logically lead to a detailed reassessment of the term-work course study programmes of each skill. More integrative skills activities may be included in order to utilise the Oxford ${ }^{\circledR}$ series full potential.

Evaluation of work on the Present Study

In terms of the aims and question of this study, it is believed that the evaluation of the proposed innovation affirmed that integrative skills teaching through the Oxford ${ }^{\circledR}$ series has been successful in significantly improving the skills proficiency of the experimental group students who undertook the course between March and June 2009 in their first term of the academic year.

In terms of professional development, the researcher plans to implement a genre based or text-based approach to teaching writing skills and evaluate its effectiveness.

\section{RECOMMENDATIONS}


Based on the findings of the present study and the survey findings done by the involved teachers, the following recommendations and implications are set forth for improving integrated skill teaching of the English language skills, especially as taught in the Oxford ${ }^{\circledR}$ series at KKU:

1. Language skill teachers should be trained to use "integration of skills" even if they are assigned to teach only one skill.

2. For the effective teaching using the "integration of skills" language teachers should be trained to adopt the materials of Oxford ${ }^{\circledR}$ series to make them comprehensible to the underprepared students of KKU.

3. The language teachers should be trained to manage the classroom time efficiently. For using the "integration of skills" a teacher needs more time than teaching a single skill.

4. The department of English should extend each class-time from 1 hour to 2 hours. It can be done easily by decreasing the number of classes.

5. Language instructors should employ language learning strategies and emphasize that a given strategy can often enhance performance in multiple skills, and reflect the integration of the skills in any language evaluation test.

\section{Pedagogical Implications}

Regarding implications for research, the present study indicates the following as in need for further investigations:

1. Learn more about the various ways to integrate language skills in the classroom (e.g., content-based, task-based, or a combination).

2. Examine potential research on the effects of integration on particular skill development such as speaking and listening or reading and writing; relate such research findings to error analysis of particular skill errors in the EFL students, and examine the interrelated nature of the literacy skills.

3. Explore the incorporation of literature teaching in an integrated skill instructional methodology for developing language skills.

4. Extend culture teaching to integrated skill instruction in the EFL classroom.

5. Examine the effects of integrated skill instruction on the abstinence or controlled use of $\mathrm{L}_{1}$ in an EFL classroom at the college level.

\section{REFERENCES}

[1] Al-Ghamari, T. (2004 April). Integrating writing with other skills. Muscat Message. 25 (2), 78-81.

[2] Allred, M. (1994). Content-based language instruction and learning a foreign language in high school: the restructuring of a learning environment. PhD Dissertation, Utah state University at Logan.

[3] Arkin, Figen. (2010). Programme evaluation: Skill-based language teaching approach in EFL. Procedia Social and Behavioral Sciences, 2, 3339-3350.

[4] Askildson, L. (2008). Phonological bootstrapping in word recognition \& whole language reading: a composite pedagogy for L2 reading development via concurrent reading-listening protocols and the extensive reading approach. Unpublished Ph.D., University of Arizona, AAT 3297984.

[5] Hao, X. \& Sivell, J. (2002 May). Integrating reading and writing in EFL composition in China. Paper presented at the annual meeting of the Canadian Association of Applied Linguistics, Toronto, Ontario, Canada, 25-28, 2002.

[6] Atkinson, D, D; Wilson, M \& Avula, D. (2005). A participatory approach to building capacity of treatment programs to engage in evaluation. Evaluation and Programme Planning, 28 (3), 329-334.

[7] Atwell, N. (1987). In the middle: writing, reading, and learning with adolescents. Upper Monclair, NJ: Boynton/Cook.

[8] Bartholomae, D. \& Petrosky, A. R. (1986). Facts, artifacts, and Counteracts: Theory and method for a reading and writing course. Portsmouth, NH: Boynton/Cook.

[9] Berninger, V. (2000). Development of language by hand and its connections with language by ear, mouth and eye. Topics in Language Disorders, 20: 65-84.

[10] Bose, M. (2003). Integrate all the skills while you teach (1). Yemen Times. Retrieved October, $23^{\text {rd }} 2011$ from: http://www.yementimes.com/print_article.html.

[11] Breen, M. P \& Candlin, C. N. (2001). The essentials of a communicative curriculum in language teaching. In D. R. Hall \& A. Hewings, (Eds.), Innovation in English language teaching: A reader (chap. 1, pp. 9-26). London: Routledge.

[12] Brown, H. Douglas. (2001). Teaching By Principles: An Interactive Approach to Language Pedagogy. (2 ${ }^{\text {nd }}$ Edition). London: Longman.

[13] Cayer, R. R. \& Sacks, R. K. (1979). Oral and written discourse of basic writers: Similarities and differences. Research in the Teaching of English, 11, 121-8.

[14] Celce-Murcia, Marianne. (Ed.). (2001). Teaching English as a Second or Foreign Language ( $3^{\text {rd }}$ Edition). Heinle and Heinle.

[15] Chamot, A. U., Barnhardt, S., El-Dinary, P. B., \& Robins, J. (1999). The learning strategies handbook. White Plains, NY: Addison Wesley Longman.

[16] Cumming, A., Kantor, R. \& Donald E. Powers (2002). Decision Making While Rating ESL/EFL Writing Tasks: A Descriptive Framework. The Modern Language Journal, 86 (1): 67-96.

[17] Daniels, H., Zemelman, S. \& Bizar, M. (1999). Whole Language works: Sixty years of research. Educational Leadership, 57(2), 32-37.

[18] Elbow, P. (1986). Writing with power: Techniques for mastering the writing process. NY: Oxford University Press.

[19] Faydi, A. (2003 February). Integrating language skills \& classroom interaction - The road to effective teaching. Muscat Message, 25 (1), 3-9. 
[20] Flora, S. (1995). A case study of literacy development through whole language in a tenth grade language arts classroom. Unpublished PhD Dissertation, School of Education, Drake University.

[21] Flower, L. \& Hayes, J. R. (1994). A cognitive process theory of writing. In R. B. RUddell, M. R. Ruddell \& H. Singer (Eds.), Theoretical models and processes of reading (pp. 928-950). Newark, DE: International Reading.

[22] Halliday, M.A.K. (1993). Towards a language-based theory of learning. Linguistics and Education. 4, 93-116.

[23] Hartley, J. (2007). Reading, Writing, Speaking and Listening: Perspectives in Applied Linguistics. Applied Linguistics, 28 (2), 316-320.

[24] Hefferman, N. (2006). An integrated approach to teaching academic writing. Asian EFL Journal, 8(3), 151-170.

[25] Henry, G \& Mark, M. (2003). Beyond Use: Understanding Evaluation's Influence on Attitudes and Actions. American Journal of Evaluation, 24 (3), 293-314.

[26] Hinkel, E. (2006). Current perspectives on teaching the four skills. TESOL Quarterly, 40 (1), 109-131.

[27] King, R. (1996). Implementing a basic college integrated reading/writing course: lessons in complexity. Unpublished PhD Dissertation, School of Education, New York University.

[28] Kleinsasser, Robert (2013). Language teachers: Research and studies in language(s) education, teaching, and learning in Teaching and Teacher Education, 1985-2012. Teaching and Teacher Education, 29 (1), 86-96.

[29] Knight, P. (2001). The Development of EFL Methodology. In Candlin, C. \& Mercer, C. (eds). English Teaching in its Social Context: A reader. London: Routledge.

[30] Krashen, S. (1981). Second language Acquisition, and second language learning. Oxford: Pergamon Press.

[31] Laine, M. (1997). Unmuted Voices: the role of oral language in developing perceptions regarding reading and writing relationships of College Developmental students. Unpublished EdD, University of Cincinnati.

[32] Landberg, G. (1993). The identification and validation of socio-psycho-linguistic strategies for integrating reading and writing at the post-secondary level. Unpublished EdD, Western Michigan University.

[33] Loban, W. D. (1963). The language of elementary school children. National Council of Teachers of English Research Report No.1. Campaign, Illinois: National Council of Teachers of English.

[34] Luo, M \& Dappen, L. (2004). Mixed-methods design for an objective-based evaluation of a magnet school assistance project. Evaluation and Programme Planning, 28, 109-118.

[35] Lynch, A. (1983). A programme to develop the integration of comprehension skills. ELT Journal, 37 (1): 58-61.

[36] Moffett, J. (1983). Teaching the universe of discourse. Boston: Houghton Mifflin.

[37] Mohan, B. (1986). Language and content. Reading. MA: Addison Wesley.

[38] Moosavi, A. (2006). Instructional effectiveness of an integrated holistic teaching method of German language at the community college level. Unpublished Ph.D., University of North Texas, AAT 3227021.

[39] Morabito, S. (2002). Evaluator Roles and Strategies for Expanding Evaluation Process Influence. American Journal of Evaluation, 23 (3), 321-330.

[40] Nunan, D. and Lamb, C. (2001). 'Managing the Learning Process'. In: Hall, D. and Hewings, A. (Eds.) Innovation in English language teaching: a reader. London: Routledge.

[41] O'Day, P. (2002). Reading while listening: increasing access to print through the use of audio books. Unpublished PhD Dissertation, Boston College, Lynch Graduate School of Education.

[42] Oxford, R. (2001). Integrated Skills in the ESL/EFL Classroom. ERIC Digest. ED456670.

[43] Oxford, R. L., \& Leaver, B. L. (1996). A synthesis of strategy instruction for language learners. In R. L. Oxford (Ed.), Language learning strategies around the world: Cross-cultural perspectives (Tech. Rep. No. 13, pp. 227-246). Honolulu, HI: University of Hawaii Press.

[44] Patton, M,Q. (2001). Evaluation, Knowledge Management, Best Practices, and High Quality Lesson Learned. American Journal of Evaluation, 22 (3), 329-336.

[45] Pawson, R \& Tilley, N (1999). Realistic Evaluation. Evaluation, Policy and Practice: Realizing the Potential. London, Sage.

[46] Pennycook, A. (1989). The concept of method, interested knowledge, and the politics of language teaching. TESOL Quarterly, 23 (4), 589-615.

[47] Preskill, H.(1994). Evaluation's Role in Enhancing Organizational Learning: A Model for Practice. Evaluation and Programme Planning, 17 (3), 291-297.

[48] Preskill, H; Zuckerman, B; \& Matthews B. (2003). An Exploratory Study of Process Use: Findings and Implications for Future Research. American Journal of Evaluation, 24 (4), 423-442.

[49] Rea-Dickins, P. \& Germain, K. P. (1992). Evaluation. Oxford: Oxford University Press.

[50] Richard-Amato, P. (2003). Making It Happen: From Interactive to Participatory Language Teaching. ( ${ }^{\text {rd }}$ edition). Pearson ESL.

[51] Richards, J. C. (1990). The Language Teaching Matrix. Cambridge: Cambridge University Press.

[52] Richards, J.C \& Rodgers, T.S. (1986). Approaches and Methods in Language Teaching. Cambridge: Cambridge University Press.

[53] Robson, C. (1993). Real World Research: A resource for social scientists and practitioner-researchers. Blackwell Publishers.

[54] Rosenblatt, L. M. (1994). The transactional theory of reading and writing. In R. B. Ruddell, M. R. Ruddell \& H. Singer (Eds.), Theoretical models and processes of reading (pp. 1055-1092). Newark, DE: International Reading Association.

[55] Ruddell, R. B. (1966). Oral language and the development of other language skills. Elementary English, 43, 489-98.

[56] Scarcella, R., \& Oxford, R. (1992). The tapestry of language learning: The individual in the communicative classroom. Boston: Heinle \& Heinle.

[57] Sehlaoui, A. S. (2001 Spring). Facing the Challenge of Teaching and Learning EFL Reading: Beyond The Language of Critique. Reading in a Foreign Language Journal, 13(2), 615-29.

[58] Shanahan. T. (2006). Relations among oral language, reading, and writing development. In C. MacArthur, S. Graham, and J. Fitzgerald (eds.) Handbook of Writing Research. New York: Guilford Press, pp. 171-83.

[59] Sridharan, S. (2003). Introduction to Special Section on 'What is a Useful Evaluation?'. American Journal of Evaluation, 24 (4), 483-487. 
[60] Stainback, S. \& Stainback, W. (Eds.), (1992). Curriculum considerations in inclusive classrooms: Facilitating learning for all students. Baltimore: Brookes.

[61] Strang, R. (1972). Developing oral expression. In H. D. Funk and D. Triplett (Eds.) Language Arts in the Elementary School: Readings (pp. 287-93). Philadelphia: J. P. Lippincott Company.

[62] Strickland, R. (1964). The contributions of structural linguistics to the teaching of reading, writing, and grammar in the elementary school. Bulletin of the School of Education, Indiana University, 40 (3), 387-395.

[63] Sullivan, R, G \& Sullivan, J, M. (1998). Evaluation Voices: Promoting evaluation from within programs through collaboration. Evaluation and Programme Planning, 21, 21-29.

[64] Thomas, L. E. (1974). Listening as an adjunct to remedial reading at the junior college level. PhD Dissertation, North Carolina State University.

[65] Tierney, R. J. \& Pearson, P. D. (1994). Learning to learn from text: A framework for improving classroom practice. In R. B. Ruddell, H. R. Ruddell \& H. Singer (Eds.), Theoretical models and processes of reading (pp. 496-513). Newark, DE: International Reading Association.

[66] Torres, R, T \& Preskill, H. (2001). Evaluation and Organizational Learning: Past, Present, Future. American Journal of Evaluation, 22(3), 387-395.

[67] Torres, R, T \& Preskill, H. (2001). Evaluation and Organizational Learning: Past, Present, Future. American Journal of Evaluation, 22 (3), 387-395.

[68] Tsung-Yuan, H. \& Oxford, R. (2002). Comparing Theories of Language Learning Strategies: A Confirmatory Factor Analysis. The Modern Language Journal, 86(3): 368-383.

[69] Vygotsky, L. (1986). Thought and language. Cambridge, MA: MIT Press.

[70] Weston, T (2004). Formative Evaluation for Implementation: Evaluating Educational Technology Applications and Lessons. American Journal of Evaluation, 25 (1), 51-64.

[71] Worthen, B; Sanders, J; \& Fitzpatrick, J. (1997). Programme Evaluation: Alternative Approaches and Practical Guidelines. New York, Longman.

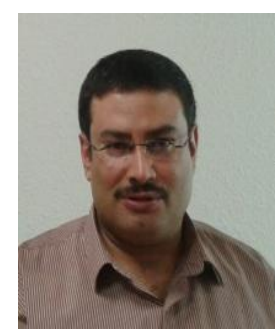

Mohamed Amin Mekheimer is an assistant professor of Applied Linguistics (TESOL-TEFL education) at the College of Languages \& Translation, English Department, King Khalid University. His major academic interests include computer-assisted language instruction research and practice, teaching, researching, and practicing translation, writing research, and researching culture in language teaching and learning. He translated 17 books in different disciplines of knowledge to several publishers and bodies, e.g., UNESCO, World Bank, and University Book House.

Hamad Shabieb Aldosari is an associate professor of Applied Linguistics (Discourse analysis) and Chairman of the English Department, College of Languages \& Translation, King Khalid University, Abha. His major teaching interests are reading and international language tests. His research interests include the investigation of the relationship between culture and language learning, and e-learning in relation to learning and teaching effects, motivational and attitudinal effects. 